\title{
Prioritisation of Information Demand of Dairy Farmers of Punjab
}

\author{
Deepak Gangil $^{1 *}$, H.K. Verma ${ }^{2}$, Jaswinder Singh ${ }^{2}$ and Neeraj Kashyap ${ }^{2}$ \\ ${ }^{1}$ College of Veterinary Science and Animal Husbandry, MHOW-453446, India \\ ${ }^{2}$ COVS, Guru Angad Dev Veterinary and Animal Science University, Ludhiana, India
}

*Corresponding author

\begin{abstract}
A B S T R A C T

\begin{tabular}{|c|}
\hline Keywords \\
\hline $\begin{array}{l}\text { Information needs, } \\
\text { Dairy Farmers, } \\
\text { Correlation }\end{array}$ \\
\hline Article Info \\
\hline $\begin{array}{l}\text { Accepted: } \\
\text { 15 December } 2018 \\
\text { Available Online: } \\
10 \text { January } 2019\end{array}$ \\
\hline
\end{tabular}

For effective extension of technologies it is utmost important that it should be based on the needs of end users. As it is the basic principle of extension that any extension programme should be based on needs and interest of the client. In the present study 300 dairy farmers were selected from five districts of Punjab i.e. Ludhiana, Barnala, Bathinda, Tarn-Taran and Hoshiarpur, to assess their information needs. The findings revealed that most essential information needs were knowledge about infectious diseases (INI=89.00), prevention and control of mastitis ( $\mathrm{INI}=86.33$ ), identification of reproductive disorders $(\mathrm{INI}=83.00)$, concentrate formulation ( $\mathrm{INI}=83.00)$, Timely heat detection $(\mathrm{INI}=81.67)$, control of ecto-parasite (INI=81.67) and knowledge about credit facilities (INI=81.67). Out of total areas health care perceived as most priority area $(\mathrm{INI}=78.33)$ followed by breeding (INI=74.67), feeding (INI=71.00), management (INI=68.00) and marketing (INI=66.33). emphasis must be given to these areas while developing strategies to disseminate technologies to the dairy farmers of this area.
\end{abstract}

\section{Introduction}

In dairy, India has reached the production of 165.4 MT but still we are far behind in terms of productivity per animal from developed countries.. Low productivity of cattle and buffaloes owned by marginal and small dairy farmers in our country is often attributed to lack of innovations and low or non-adoption of innovations/improved production technologies (Triveni, 2016). Poor reach of the information to the farmers is major reason behind it. In present day agriculture, soft resources like knowledge and skills are as important as hard resources like inputs, and sometimes more important. Quick dissemination of technological information from the research system to farmers in the field and reporting of farmers' feedback to the research system is one of the critical inputs in transfer of technology (Subhas et al., 2015). For effective dissemination of the technologies it is very important to take care of needs of the farmers, which is also important for the scientist to initiate the research as per the farmer's needs. Need is basically as a gap between "what is" (present situation) and "what ought to be" (desired situation). Informational needs are basically incompetency felt by the farmers in dairy 
farming activities and needs the technical advice from authentic sources for taking effective decision for action. Use of ICT can play an effective role in dissemination of need based information to the farmers. Study of information needs of the dairy farmers are very important in understanding the farming situations at field level as most of the time farmers themselves may not be aware that they are deficient in some information. Keeping that in mind present study was carried out with following objectives:

Assessment of information needs of dairy farmers;

To study the relationship between information needs and socio-economic and communication profile of the farmers.

\section{Materials and Methods}

Present study was carried out in five district of Punjab i.e. Ludhiana, Barnala, Bathinda, TarnTaran and Hoshiarpur. Multistage random sampling was adopted for selection of respondents. Three villages were selected from each district and twenty dairy farmers from each village making total of 300 dairy farmers for assessment of information needs especially for development of text messages to be disseminated through mobile. The data were collected through a pretested structured interview schedule. The information needs of the farmers were accessed in different areas of dairy farming i.e. breeding, feeding, health care management and marketing. Responses were taken on a 3 point continuum i.e. most essential, essential and least essential with their respected scores as 32 and 1. The dairy farmers were asked to indicate their preference in the respective areas and sub areas of dairy farming. In order to find out the priority area of information the mean score was calculated by multiplying the frequency number of respondents in each area with respective score allotted to most essential, essential and least essential categories and summation. Ranking were done on the basis of Information Need Index calculated by following formula as per Patil and Kokate (2011) with slight modifications.

Weighted Score $(\mathrm{WS})=(\mathrm{MN} \times 3)+(\mathrm{N} \times 2)+$ $(\mathrm{LN} \times 1)$

$$
\begin{aligned}
& \text { Total Obtained score } \\
& \text { INI = Maximum obtainable score } \\
& \text { MN = Frequency of respondents opted for } \\
& \text { Most Essential } \\
& \mathrm{N} \quad=\text { Frequency of respondents opted for } \\
& \text { Essential } \\
& \text { LN = Frequency of respondents opted for } \\
& \text { Least Essential }
\end{aligned}
$$

To find out the relationship between independent variables and information needs correlation coefficient (r) was calculated and tested for level of significance.

\section{Results and Discussion}

\section{Information needs related to breeding practice}

A cursory look from the Table 1 indicates that identification of reproductive disorders (INI=83.00), Timely heat detection $(\mathrm{INI}=81.66)$ and selection of animals (INI=78.33) were at first second and third rank as per the priority of the farmers. As reproductive problems leads to huge economic losses and in absence of knowledge regarding it leads to poor production. Timely heat detection is very much important in dairy farms as a missed heat will lead to loss of 21 days production. Present finding is in agreement with Subash et al., (2015) and Sharma (2016) who also reported that heat detection was most needed area as perceived 
by majority of farmers. Similarly Teja (2013) reported that eighty percent farmers needed information on reproductive disorders and perceived it as important. It is very important to choose quality animals during purchase and farmers feel that they must have knowledge about different criteria like breed characteristics, record of dam and sire and parity of animals. Similar findings had also been reported by Subash et al., (2015), Laldinpuii (2013) that selection of animals was mostly needed area of information by majority of farmers.

Further time of insemination (INI=73.00), age and weight at sexual maturity ( $\mathrm{INI}=70.00$ ), pregnancy diagnosis (INI=69.00) and knowledge of different dairy breeds (INI=67.66) were at fourth, fifth, sixth and seventh rank respectively. Right time of insemination/service will provide better conception rate leading to shorter calving interval. Education and awareness of farmers regarding this would result in more animals being inseminated at an optimal time and a higher pregnancy result. Similarly Raina et al., (2017) revealed that insemination and its role (TNI=88.22) was indicated as most important information need of farmers. Meena and Fulzele (1997) also found pregnancy diagnosis and time of insemination were the needed area of training.

\section{Information needs related to Feeding practices}

Feeding of dairy animals is important part of dairy farming as feeding alone accounts for 70 percent of the expenses incurred for dairying and directly linked with production and reproduction of farm animals (Table 2).

Results indicate that concentrate formulation is most essential information need (INI=83.00) followed by feeding of by-pass fat (INI=76.67) and supplementation of mineral mixture (INI=75.66). This may be due to that farmers want to know the formulation of concentrate ration at their home, as readymade concentrate might be costly for the farmers. Accordingly Subhas et al., (2015) found most information need in feeding practice were preparation of balanced ration (51.7\%), bypass feed technology (53.3\%) and knowledge about mineral mixture (46.7\%). Rajput et al., (2012) reported that dairy farmers mostly required training regarding feeding of mineral mixture and legumes followed by balanced feed and its composition.

Other essential information needs like feeding of pregnant animals (INI=71.00), followed by silage making (INI=67.33), calf feeding (INI=62.00) and UMMB lick (INI=60.66) and were ranked as fourth, fifth, sixth and seventh. Information about feeding of pregnant animals is important as pregnancy ration is responsible for the calf growth and also for the production in coming lactation. Silage preparation is important technology and can be used specially during fodder shortage. Kale et al., (2013) also reported that over three fourth of the respondents $(78.00 \%)$ expressed their needs for training in feeding of pregnant cows/buffaloes and majority (60.00\%) perceived silage making as needed area in which they need information.

\section{Information needs related to health care practices}

Health care management ensures the wellbeing of animals and reduces production losses due to diseases. Results of the information needs of dairy farmers in various health care practices are presented in Table 3. It can be viewed that knowledge about infectious diseases (INI=89.00) followed by prevention and control of mastitis (INI $=86.33$ ) and control of Ecto-parasites (INI=81.67) were the most essential information need expressed by farmers and ranked as first, 
second and third respectively. This may be due to the fact that infectious diseases affect the dairy animals leading to morbidity and mortality, so farmers were keen to know about these diseases so that they can effectively protect their animals against these ailments. Mastitis is very common disease in farm animals specially high producing cattle that causes loss in milk production and also hampers the milk quality. Farmers interested to know about the preventive measures and its early detection to control this disease and can prevent their losses. In Punjab due to hot and humid climate external parasite caused big nuisance to the farm animals. So farmers interested to know about effective control of these parasites. Raina et al., (2016) reported similar findings that majority of the respondents opined identification of common diseases $(\mathrm{TNI}=97.33)$ was the major training area. Patil et al., (2009) also found that majority of the farmers $(71.56 \%)$ expressed needs to have training in information about infectious diseases as most important. Durgga and Shubhadra (2009) also reported identification of symptoms of important disease as most needed area for skill training. The farm women might have been interested to know about the control and identification of important diseases. According to Jacob and George (2013) Symptoms of common diseases was the most needed training area expressed by majority of the respondents (TNI=93.33) followed by control of ectoparasites (TNI=86.67), deworming (TNI=76.67), vaccination $(\mathrm{TNI}=73.33)$, identification and isolation of sick animals (TNI=63.33).

Further first aid treatment (INI=78.00), vaccination schedule (INI=72.33), deworming (INI=71.67) and isolation of sick animals $(\mathrm{INI}=68.33)$ fell in essential category information needs and were ranked as fourth, fifth, sixth and seventh respectively as these practices are important and needed routinely in animals health care managements. Teja (2013) reported that majority of women self- help group (WSHG) members $(85.56 \%)$ need information about treatment of simple ailments.

\section{Information needs related to management practices}

Management of dairy animals is a key to success of dairy farm as efficient management will lead to improve quality and quantity of production and is necessary for running a dairy farm as profitable venture. Information needs of dairy farmers in various management practices are presented in Table 4.

Results indicate that seasonal management of dairy animals (INI=76.33) followed by clean milk production (INI=74.67) and care at calving (INI=73.00) were perceived as essential information needs and were ranked first, second and third respectively. Farmers were keen to know about management of dairy animals in different seasons due to encounter with extreme climate, season plays important role in animal's management. Increase awareness of consumers regarding milk quality, farmers was also interested to know about different measures to produce clean milk. Calving is important stage of farm animals management and farmers need information about care at the time of calving. Rajput et al., (2012) also found care at calving as essential area for training as perceived by majority of farmers. Subash et al., (2015) reported that 65 percent of farmers expressed clean milk production as most important information need.

Other management practices to which farmers were interested and expressed as essential were housing of animals (INI=69.67) followed by weaning $(\mathrm{INI}=67.33)$ and care of new born calves ( $\mathrm{INI}=66.67)$ and were ranked as fourth, fifth and sixth respectively. Interest in information regarding proper housing of animals may be due to that it is an important area that prevents animals against extreme 
climatic conditions like direct sunshine, cold etc. Uncomfortable housing will lead to stress in animals and results production losses. Raina et al., (2016) reported that housing layout design (TNI= 66) is important training area as perceived by the farmers. Dehorning/disbudding of calves were perceived as least essential area (INI=49.33) and was rank at the last. This may be due to the fact that most of the buffalo farmers do not practice disbudding in buffalo calves and in crossbred, majority of farmers already followed this practice.

Table.1 Information needs related to breeding practices

\begin{tabular}{|c|l|c|c|c|c|}
\hline $\begin{array}{c}\text { S. } \\
\text { No. }\end{array}$ & \multicolumn{1}{|c|}{ Breeding practices } & $\begin{array}{c}\text { Weighted } \\
\text { score }\end{array}$ & $\begin{array}{c}\text { Mean } \\
\text { score }\end{array}$ & INI & Rank \\
\hline $\mathbf{1}$ & Selection of animals & 705 & 2.35 & 78.33 & III \\
\hline $\mathbf{2}$ & Knowledge about dairy breeds & 610 & 2.03 & 67.66 & VII \\
\hline $\mathbf{3}$ & Timely Heat detection & 737 & 2.45 & 81.66 & II \\
\hline $\mathbf{4}$ & Age \& weight at sexual maturity & 630 & 2.10 & 70.00 & V \\
\hline $\mathbf{5}$ & Time of insemination & 659 & 2.19 & 73.00 & IV \\
\hline $\mathbf{6}$ & Pregnancy diagnosis. & 621 & 2.07 & 69.00 & VI \\
\hline $\mathbf{7}$ & Identification of reproductive disorders & 748 & 2.49 & 83.00 & I \\
\hline
\end{tabular}

Table.2 Information needs related to feeding practice

\begin{tabular}{|c|l|c|c|c|c|}
\hline $\begin{array}{c}\text { S. } \\
\text { No. }\end{array}$ & Feeding practices & $\begin{array}{c}\text { Weighted } \\
\text { score }\end{array}$ & $\begin{array}{c}\text { Mean } \\
\text { score }\end{array}$ & INI & Rank \\
\hline $\mathbf{1}$ & Concentrate formulation & 749 & 2.49 & 83.00 & I \\
\hline $\mathbf{2}$ & Feeding of calf & 559 & 1.86 & 62.00 & VI \\
\hline $\mathbf{3}$ & $\begin{array}{l}\text { Supplementation of mineral } \\
\text { mixture }\end{array}$ & 682 & 2.27 & 75.66 & III \\
\hline $\mathbf{4}$ & Feeding of pregnant animals & 641 & 2.13 & 71.00 & IV \\
\hline $\mathbf{5}$ & By-pass fat & 690 & 2.30 & 76.67 & II \\
\hline $\mathbf{6}$ & UMMB Lick & 548 & 1.82 & 60.66 & VII \\
\hline $\mathbf{7}$ & Silage making & 607 & 2.02 & 67.33 & V \\
\hline
\end{tabular}

Table.3 Information needs related to health care practices

\begin{tabular}{|c|l|c|c|c|c|}
\hline S. No. & \multicolumn{1}{|c|}{ Health care practices } & Weighted score & $\begin{array}{c}\text { Mean } \\
\text { score }\end{array}$ & INI & Rank \\
\hline $\mathbf{1}$ & Knowledge about infectious diseases & 801 & 2.67 & 89.00 & I \\
\hline $\mathbf{2}$ & Deworming & 645 & 2.15 & 71.67 & VI \\
\hline $\mathbf{3}$ & Isolation of sick animals & 615 & 2.05 & 68.33 & VIII \\
\hline $\mathbf{4}$ & Ectoparasite control & 748 & 2.49 & 81.67 & III \\
\hline $\mathbf{5}$ & Vaccination schedule & 651 & 2.17 & 72.33 & V \\
\hline $\mathbf{6}$ & First aid treatment & 704 & 2.34 & 78.00 & IV \\
\hline $\mathbf{7}$ & Prevention and control of mastitis & 777 & 2.59 & 86.33 & II \\
\hline
\end{tabular}


Table.4 Information needs related to management practices

\begin{tabular}{|c|l|c|c|c|c|}
\hline S. No. & \multicolumn{1}{|c|}{ Management practices } & $\begin{array}{c}\text { Weighted } \\
\text { score }\end{array}$ & $\begin{array}{c}\text { Mean } \\
\text { score }\end{array}$ & INI & Rank \\
\hline $\mathbf{1}$ & Care at calving & 659 & 2.19 & 73.00 & III \\
\hline $\mathbf{2}$ & Care of new born calves & 601 & 2.00 & 66.67 & VI \\
\hline $\mathbf{3}$ & Dehorning/disbudding & 445 & 1.48 & 49.33 & VII \\
\hline $\mathbf{4}$ & Seasonal management & 687 & 2.29 & 76.33 & I \\
\hline $\mathbf{5}$ & Weaning of calves & 608 & 2.02 & 67.33 & V \\
\hline $\mathbf{6}$ & Clean milk production & 672 & 2.24 & 74.67 & II \\
\hline $\mathbf{7}$ & Housing of animals & 627 & 2.09 & 69.67 & IV \\
\hline
\end{tabular}

Table.5 Information needs related to marketing practices

\begin{tabular}{|c|l|c|c|c|c|}
\hline S. No. & Marketing practices & $\begin{array}{c}\text { Weighted } \\
\text { score }\end{array}$ & $\begin{array}{c}\text { Mean } \\
\text { score }\end{array}$ & INI & Rank \\
\hline $\mathbf{1}$ & $\begin{array}{l}\text { Knowledge about credit } \\
\text { facilities }\end{array}$ & 737 & 2.45 & 81.67 & I \\
\hline $\mathbf{2}$ & $\begin{array}{l}\text { Government schemes } \\
\text { (insurance) }\end{array}$ & 670 & 2.23 & 74.33 & II \\
\hline $\mathbf{3}$ & Milk testing techniques & 449 & 1.49 & 49.67 & V \\
\hline $\mathbf{4}$ & Marketing Channels & 586 & 1.95 & 65.00 & III \\
\hline $\mathbf{5}$ & Maintenance of records & 556 & 1.85 & 61.67 & IV \\
\hline
\end{tabular}

Table.6 Relationship between independent variables and Information needs of respondents in various practices

\begin{tabular}{|l|c|}
\hline Independent Variable & Correlation Coefficient ' $\mathbf{r}^{\prime}$ value \\
\hline Age & $-.201^{* *}$ \\
\hline Education & $0.069 \mathrm{~ns}$ \\
\hline Family size & $.228^{* *}$ \\
\hline Family type & $0.103 \mathrm{~ns}$ \\
\hline Land holding & $.371^{* *}$ \\
\hline Herd size & $.519^{* *}$ \\
\hline Milk Production & $.428^{* *}$ \\
\hline Milk Sale & $.400^{* *}$ \\
\hline Training & $0.12 \mathrm{~ns}$ \\
\hline Mass Media Exposer & $.386^{* *}$ \\
\hline Extension Contacts & $.510^{* *}$ \\
\hline
\end{tabular}


Fig.1 Information needs in overall areas of dairy farming

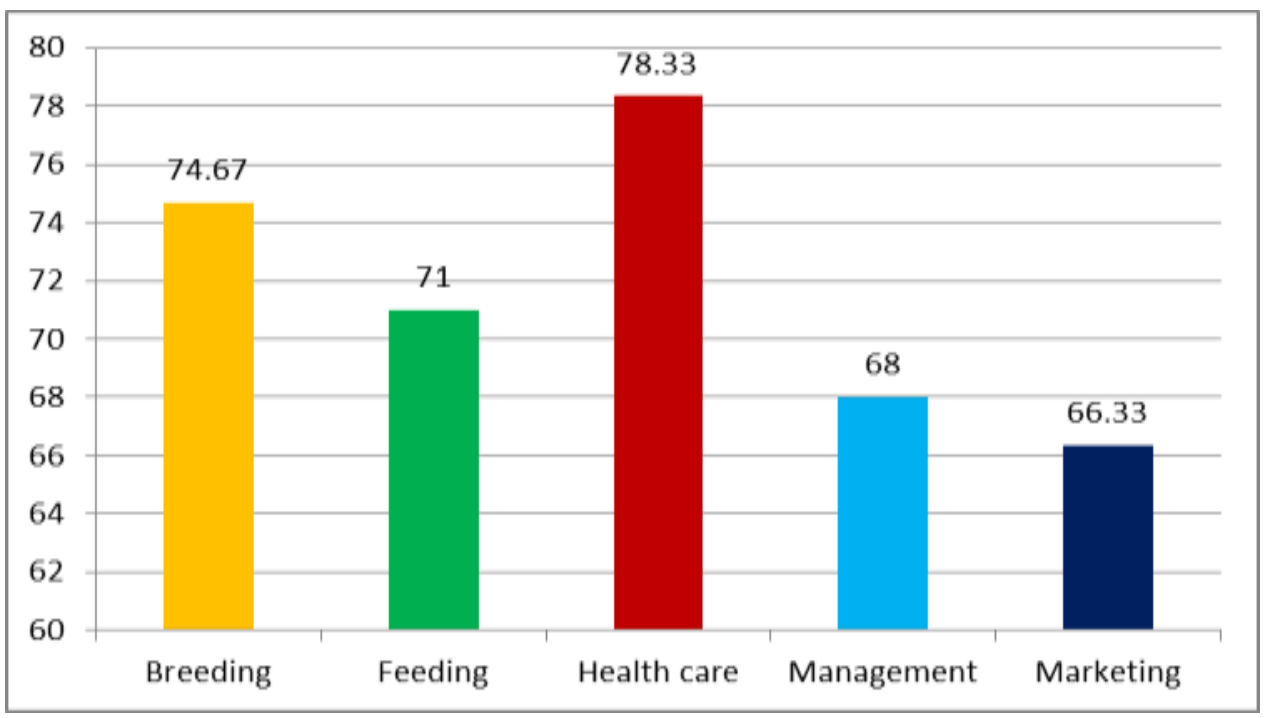

Information needs related to marketing practices

Results on information needs of farmers regarding various marketing practices are presented in Table 5.

From the perusal of Table 5 it can be observed that majority of farmers perceived knowledge about credit facilities (INI=81.67) as most essential followed by Government schemes (INI=74.33) and marketing channel for milk and milk products $(\mathrm{INI}=65.00)$ and rank wise they appeared as first, second and third respectively. This preference of farmers may be due to requirement of regular investments in dairy business to meet out daily expenses on feeds, medicine etc. moreover farmers may also have interest to expand their farm. For these, they require credit and they want to have information about getting credit for dairy business. Similarly, information about government schemes and subsidies may not reach to them timely.

Present findings are in agreement with the earlier findings of Sharma (2016) and Singh et al., (2016), they observed that majority of farmers were interested to get information about government subsidies for dairy farming. Further, farmers expressed importance of record keeping (INI=61.67) as essential whereas milk testing were perceived as least essential ( $\mathrm{INI}=49.67)$. Present preference of the farmers may be due to that by record maintenance they can better manage their farms and take decisions accordingly. While farmers may not be interested to test their milk as they might not perceived benefits of milk testing.

From figure1, it was observed that out of total areas health care related practices perceived as most priority area (INI=78.33) followed by breeding (INI=74.67), feeding (INI=71.00), management (INI=68.00) and marketing (INI=66.33). It may be due to that farmers mostly encounter animal health problem and also reproductive disorders and due to technical aspect, they had comparative low knowledge on these areas, therefore they prefer to have more information about these practices. Present findings were in conformity of Gupta and Tripathi (2002) and Gangil et al., (2005) they reported that health care and breeding were priority areas for training. 
Relationship between socio-economic, communication profile of the respondents and information needs

Correlation coefficients between socioeconomic, communication profile of the respondents and information needs are presented in Table 6. Results reveal that age of the respondents has negative and significant $(\mathrm{P}<1 \%)$ correlation with their information needs. This means that younger farmers need more information on dairy practices as they are less experienced and expressed more desire for information. It was also observed that information needs had positive and significant relationship with land holding, herd size of the respondents. That means respondents with larger size of land and more no of animals need more information than the respondents with small land holding and smaller herd size. This could be due to the fact that there could be the chance to increase the size of their dairy farm, if the land holding is more leading to higher returns from dairy farming. Respondents with larger herd size have higher information needs may be due to more requirement of information to manage larger herds.

Similar pattern of relationship i.e. positive and significant $(\mathrm{P}<1 \%)$ relationship has also been observed in between information needs and milk production, sale, mass media exposer and extension contacts. It could be due to the respondents with higher milk production and sale seeks more information, to maximize their profit, from different sources i.e. through mass media and extension contacts and they might not be satisfied with the information received and have more interest to gain information from reliable and credible source. i.e. GADVASU, Ludhiana. Okwoche et al., (2015) reported that the probability of farmers having interest in receiving training increases with farm income, education, herd size, farming experience and no. of extension contacts.

Correlation coefficient (r) value for information needs was non-significant at 1 per cent and 5 per cent with education, family type and training of respondents. That means these variables do not affect the information needs of the farmers. From the present study it can be concluded that among various dairy husbandry practices identification of reproductive problems, regular heat detection, concentrate formulation, knowledge about infectious diseases, prevention and control of mastitis, ecto-parasites control and knowledge about credit facilities were most essential needs of dairy farmers. Land holding, herd size, milk production, milk sale, mass media exposure and extension contacts were the major contributory factors in deciding the information needs of the farmer. Dairy farmers should have access to these needed information for better management of their animals and to take correct decisions at right time. Identification of information needs enables the extension agencies to make effective strategies for dissemination of technologies.

\section{References}

Durgga, R. V. and Shubhadra, M. R. 2009. Training needs of farm women in dairy farming Veterinary World, 2(6): 221223.

Gangil D, Bardhan D, Dabas Y P S and Kumar A. 2005. Identification of training needs of livestock farmers in improved animal husbandry practices in Tarai area of Uttaranchal. Indian Dairyman, 57(5): 47-49.

Gupta, M. and Tripathi, H. 2002. Assessment of training needs of rural women in dairy enterprise. Indian J. Dairy Sci., 55(3): 178-182.

Jacob, S. K. and George, A. 2013. Assessing 
the Training Need of Dairy Farmers on Scientific Cattle Management Practices. International journal of scientific research, 2(7): 496-97

Kale, R. A., Tekale, V. S. and Dhere, R. V. 2013. Training needs of farm women in dairy farming. Agriculture update: 8(4): 583-58

Meena, B. L. and Fulzele, R. M. 1997. Assessing training needs of tribal women. Maharastra Journal of Extension Education 16: 316-320

Okwoche, V. A., Abu, O. and Hon, F. A. 2015. Analysis of training needs by livestock farmers in Benue state, Nigeria. European Journal of Research in Social Sciences, 3(2): 55-60.

Patil, A. P., Gawande, S. H., Gobade, M. R. and Nande, M. P. 2009. Training needs of dairy farmers in Nagpur district. Vet. World, 2(5): 187-190.

Patil, S.S. and Kokate, K.D. 2011. Training need assessment of subject matter specialists of Krishi Vigyan Kendras. Indian Res. J. Ext. Edu., 11(1): 18-22.

Raina, V., Sharma, N., Khajuria, S., Kumar, K., Choudhary, S., Syed, Z. H. and Hussain, K. 2017. Training needs of dairy farmers. International Journal of Agriculture, Environment and Biotechnology, 10(2): 245-51.

Rajput, B. P. S., Sahu, N. C., Kant, K. and Kumar, R. 2012. Perceived training needs of dairy farmers regarding improved dairy farming practices and its relation with their socio-economic traits in Bundelkhand Region. Indian Journal of Dairy Science, 65(4): 34247.

Sharma, A. 2016. 'An analysis of adoption of scientific dairy farming practices disseminated through NDRI messaging portal'. M.Sc. Thesis, National Dairy Research Institute, Karnal, India.

Singh, N., Malhotra, P. and Singh, J. 2016. Information needs and seeking behavior of dairy farmers of Punjab. Indian Journal of Dairy Science, 69(1): 98104.

Subash, S., Gupta, J. and Babu, G. P. 2015. Information needs assessment and prioritization of dairy farmers. Journal of Krishi Vigyan, 4(1): 51-55.

Teja, J. 2013. 'Effectiveness of mobile telephony in dissemination of information among livestock based WSHGs - An exploratory study'. M.V.Sc. Thesis, Sri Venkateswara Veterinary University, Rajendranagar Hyderabad, India.

Triveni, G. 2016. A critical analysis on rate of adoption and diffusion of dairy innovations and formulation of suitable extension methodologies. PhD Thesis, P.V. Narasimha Rao Telangana Veterinary University.

\section{How to cite this article:}

Deepak Gangil, H.K. Verma, Jaswinder Singh and Neeraj Kashyap. 2019. Prioritisation of Information Demand of Dairy Farmers of Punjab. Int.J.Curr.Microbiol.App.Sci. 8(01): 22042212. doi: https://doi.org/10.20546/ijcmas.2019.801.230 